《解 説》

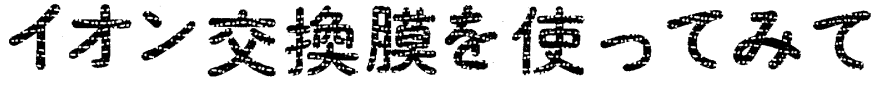

椎 尾

\section{イオン交換膜を使って，亜鉛メッキ排液回 収実験について述べる}

\section{1. はじめに}

最近，イオン交換膜をメッキ工程に利用す ることが增えてきたので，“イオン交換膜を 使ってみでとでもいった解説党書いてみ る。

なるべく固苦しい説明は奴さにして，使用 経験の久を書くとよいのでするが，予備知識 を全くもたない人のた的に，ここで概略の説 明を述べてみる。

イオン交換膜はイオン交換樹脂を多孔質膜 状にしたようなもので，陰イオンのみを通す アニオン膜 (以下A膜) と陽イオンの多通 すカチオン膜 (C膜) がある。

最初は海水の脱塩による淡水化, または濃 縮による製塩にもっぱら使用されていた。こ の場合， A膜， C膜を交互に使って電気透析

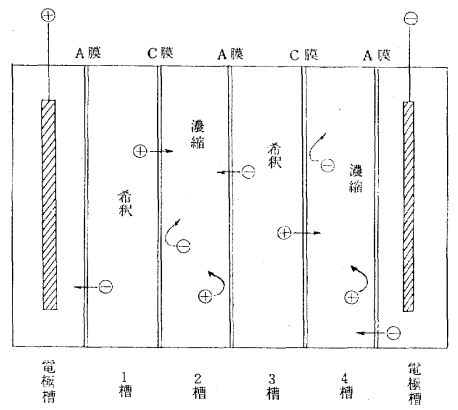

図1イオン交換膜による電気透析略図
を行ない，1，3 槽では希釈，2，4 槽では 濃縮が図 1 の如くに行なわれる。実際柱，能 率をあげるために各室の厚みを $2 \sim 3 \mathrm{~mm}$ K し, 数 10 組連結し, 両端に電極室を設ける。

この際, イオン交換膜表面と透析室内部々 の間でイオン濃度差が生じると能率が悪くな るので, 透析液をカクハンしたり，貯液槽か ら液を激しく流入させたりする。

メッキ工程へ応用する場合, 色々な使い方 が考穴られる。その 1 つはメッキ排水，回収 槽液などを濃縮してメッキにもどしたり，重 金属イオンを回収したりなる方法で，この場 合は図 1 の製塩装置と同じ構成で行なら。

この㴽か，クロメート液の再生や，酸洗廃 液の再生, 不純物除去などの特殊用途に種々 用いることができるが，この場合は，陽イオ ンまたは陰イオンのみなどと特定のイオンの 透析が多いので，図 1 の一般的な構成とは別 に，図 2，3のような各用途に適した方法で 使わ水ている。

ところで，イオン交換膜を通常の用途，例 总ばニッケルメッキ排液の回収や，酸洗廃液 の再生などに用いるときは既製の市販装置を 買ってきてボタンを押すだけで使用できるこ とが多いのであるが，これらをメーカー指定 以外の用途や，条件で動かすときはやはりイ オン交換膜の性質を理解していなければなら。 ない。 


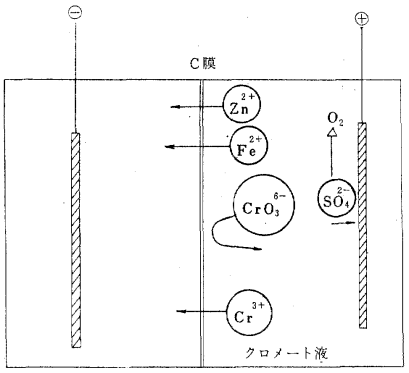

図 2 クメート液再生装置例

また自分で工夫して変わった用途を開発す る場合も，当然膜の知識を必要とする。

われわれのところでは昭和 47 年頃からイオ ン交換膜による覀鉛メッキ排液の回収実験を 行なったので，そのとさに実際に経験した事 柄を少し述べてみたい。

亜鉛メッキの回収といら特殊な実験であっ たか子知れないが，色々とイオン交換膜の特 性といらものに接したので，これから膜を使 ってみようと思うかたの参考になれば幸いで ある。

\section{2. 液もれに泣かされる}

液もれといっても, 別にピンホールなど膜 に欠陥があったわけではない。

透析装置は市販品を使ったが，イオン交換 膜は種々のタイプのものを取り換觉て実験を した。透析槽は断面積 $10 \times 20 \mathrm{~cm}$ ，厚さ 0.3 $\mathrm{cm}$ 位の太鼓の胴のような形をして扣り，間 に膜をはさんでいくつかつなぎ，全体をボル トでしめつけるわけであるが，四方が均一 に, しっかりしめつ汓られないと透析槽と膜 の間からポトポトと液がもれる。

あまり強くしめると塩化ビニル製の透析槽 にヒビが入る。膜と槽の間を接着剤でふさぐ とよいかも知れないが，膜の種類によっては 乾燥されると性能が悪くなるということで, たえず水でしめらせてあり，溶媒系の接着剤

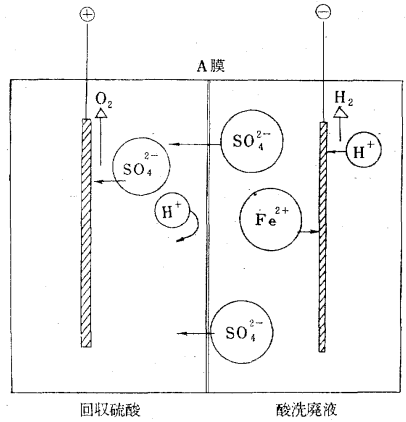

図 3 酸洗廃液回収装置例

は使用できず，また水溶性ののりは固まらな W。

そこで，何回もしめな抗しては通水し，水 圧がかかってももれないよらにするのに苦労 した。

液もれはこれだけではない。透析槽と膜の 間の液もれが止まってしめたと思って実験を 行なってみると，実験結果がばらついて困っ たものである。これは，膜を通しての液もれ によるのではないかと考壳られ，電圧を切 り，通液の久行なってみると，はたして濃度 の変化があらわれた。

イオン交換膜は多孔質の半透膜であるので 膜の両側で水圧が異なると液の移動が生じ る。したがって，濃縮槽，希釈槽とで，通液 する流速を同じにして，膜の両側での静水圧 のみでなく，動圧までひとしくしないと液の 移動が起こってしまう。市販の透析装置に 认，陰・陽電極槽, 濃縮槽, 希釈槽へ各貯槽 から通液する管に流量計が付いているが，こ の読みをなるべく正確に同じにするよらに各 水流ポンプを調節する必要がある。

イオン交換膜を通しての液もれに，むう 1 つ電気浸透によるものが考觉られる。これは 固体と液体が接触していると，その界面に電 気 2 重属が生じ，電圧をがると固体を固定 して打液体が動く現象による。イオン交 
換膜の細孔には, 陰, 陽どちらかに荷電した 官能基がついて拉り, 反対荷電のイオンのみ を通過させるわけであるが，溶媒である水と の間にも電気 2 重層が生じているので, 電気 透近を行ならと, 膜が固定されているので膜 を通して水の移動が起こる。

この電気浸透による液もれがどの程度起こ るのか, 初めは相当心配していた。しかし実 際に実験を行なってみると，各透析槽貯槽の 液量が，汪とんぞ変化しないので，あまり影 響を执よぼしていないようであった。

今回の実験の条件が，極間電圧 $30 \sim 40 \mathrm{~V}$ 電 圧勾配 $2 \sim 3 \mathrm{~V} / \mathrm{cm}$ 程度と少ないので, 電 気浸透はあまり起こらなかった。るっと電圧 をあげ，電流を多く流して，限界電流（普通 のイオン交換膜では $5 \sim 6 \mathrm{~A} / \mathrm{dm}^{2}$ ) 飞近づ いてくると, 膜を通るイオンの速度がにぶ り, 膜の両側での電圧降下が大きくなり, 電 気浸透や水の電解が起こるようである。

今回の実験は, せいぜい $2 \mathrm{~A} / \mathrm{dm}^{2}$ までで あったので, こうした液もれは考兄なくても よかったので放る。

\section{3. 亜鉛は全部陰イオンになっていた}

イオン交換膜の実験をやっていると, 副産 物として色々と新しいことがわかってくる。 亜鉛メッキシアン浴中で，亜鉛がどのような 形で存在するか興味のある問題であった。る らろん, 大部分の亜鉛は, $\mathrm{Zn}(\mathrm{CN})^{2-}{ }_{4}$ とな って特り, 1 部か $\mathrm{Zn}(\mathrm{CN})_{3}(\mathrm{OH})^{2-}, \mathrm{Zn}(\mathrm{C}$ $\mathrm{N})_{2}(\mathrm{OH})_{2}^{2-や, な か に は ~} \mathrm{Zn}(\mathrm{CN})_{3}\left(\mathrm{H}_{2} \mathrm{O}\right)$ 一な ど，汪とんどが負のイオンになっていると考 えられる。

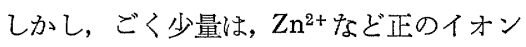
も存在し, これらの正・負両イオン群の間で 化学平衡が成立して特り,メッキはこの小量 存在する $\mathrm{Zn}^{2+}$ によって行なわれているので はないかと想像していた。

このように考えると, シアン浴中の亜鉛は
正・負両イオンが存在することになるので， 電気透析を行なうと, 大部分はアニオン交換 膜を通って透析されるが，カチオン交換膜を 通過する亜鉛もあることになる。

そこで図 4 の如く透析槽を構成して，3室 にシアン化亜鉛メッキ液を入れ，2拉よび 4 室に透析されてくるイオン濃度を測定してみ た。分析は亜鉛, シアンについてのみ行なっ たが, $2 \mathrm{~A} / \mathrm{dm}^{2}$ で 6 時間透析を行なっても， 2 室には少しも亜鉛, シアンが移動せず, 4 室にのみ透析された。分析の感度以下のこと は分らないが，この結果から考光ると，亜鉛 はシアン浴中で全部負のイオンになっている とみるべきであるら。こうなると負の尋鉛錯 イオンが，陰極の製品に電着するメッキの機 構を考学て及なければならない。

負のイオンから陰極汇電着されるメッキと しては，代表的なものにクロムメッキがあ る。これは一 2 荷のクロム酸イオンを陰極表 面で水素により還元し，クロム酸クロム，采 たは正のクロムイオンに変えて電着させると 考兄られる。

したがって，シアン浴からの亜鉛メッキ も，負の亜鉛錯イオンが，陰極表面に郝ける 電極反応により分解され, その結果, 生成さ れた金属イオンが陰極上電着されると思わ れる。このようにイオン交換膜は, メッキ排 液からの重金属回収などの利用の深が，メ

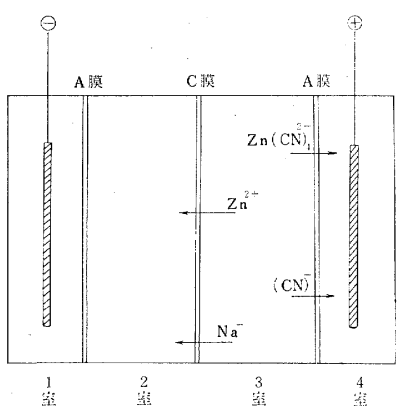

図 4 交換膜比選択性実験装置 
ッキ浴の構成, 電着機構の解明など多くの利 用法が考光られる。

\section{4. 透析電流がふえると大きなイオンは通り にくくなる}

大きなイオンといってもなにが大きいのか 問題である。ナトリウムイオンや塩素イオン にくらべて，业鉛シアン錯イオンや硫酸イオ ン，クロム酸イオンのように複合されてでき ているイオンは形状的に大きなイオンにな る。

一方，マグネシウムイオンはナトリウムイ オンにくらべて形状的には小さいが，電荷と しては大きなイオンとなる。イオン交換膜の 通りやすさは，細孔をくぐりぬけるためには 形状が小さい添ど有利であり，また官能基の 電気的引力をらり切るには電荷の小さい添う が有利となり，外部電場は電荷の大きい添ど 影響を受ける。

官能基との相互作用は静電的作 用の添か に，水素結合や双極子， 4 極子間の作用，官 能基とイオンとで作った塩の解離常数など多 くの因子が考壳られる。

イオン交換膜を通って透過する機構を図 5 のように考光，その過程を次の 5 つに分けて みた。

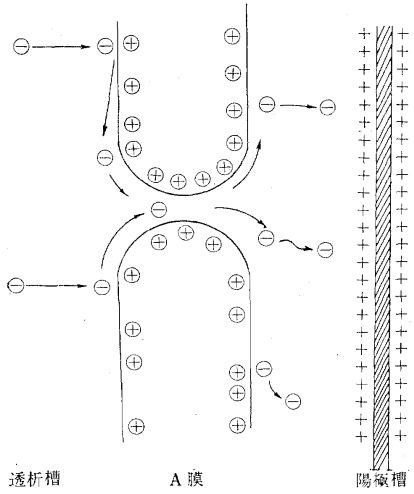

図 5 イオン交換膜透析モデル
(1) 左の槽中で液中よりイオンが膜面へ濃 度拡散により移動する。

(2) 膜面の官能基江着平衡が成り立つ。

(3) 濃度差, 電場の作用などにより, 吸着 層中での 2 次元拡散が起こり, 細孔を通 過する。

(4) 膜面官能基より脱離する。

(5) 膜面より液中に抎散する。

このうち，(1)，(5)送水ポンプなどではげ しくカクハンすれば，考党なくてもよくなる と思われる。(2)，(4)のイオン交換膜之溶液間 での吸着, 脱離平衡に関する項は膜の特性の ほかに溶液の濃度が影響すると考えられ，当 然濃い液から薄い液にイオンを透析するのが いちばん容易となる。

膜の両面での液濃度差が少なくなったり， 濃度差が逆転して薄い液から濃い液へイオン を透析しようとするときに注この因子は逆に 作用するので，電気的に大さな負荷を要する ことになると思われる。(3はまったくイオン 交换膜の特性にもとづくもので，使用目的に あわせて細孔径や官能基の種類, 量を調節乙 なければならない。

しかし，扮招すじからいって，大きなイオ ンが通りやすいようにすれば，小さいイオン は当然楽汇通過できると考兄られ，小さな1 オンに対して大きなイオンがあまり差がな く，移動できるかどらかの調節ができるだけ のようでめる。

したがって，透析電流をふやして移動速度 を速めたり，次に述べる濃度拡散にさからっ て呩い液の㴗うへ透析したりするような，む りをさせると大きなイオン漂どついていけな くなる。

例㓪ば，亜鉛メッキシアン浴の $1 / 5,1 / 10$ 希釈液のイホン交換膜透析実験に括いて，透 析電流と移動した亜鉛 (シアン錯イオン), シアン (全シアン) の測定值を表 1 亿示した が， $2 \mathrm{~A} / \mathrm{dm}^{2}$ 位になってくると亜鉛錯イオ 
ンのよらな大きなイオンの 移動は著しく減少してい る。

液組成と大体ひとしい割 合で透析できるのは $1.5 \mathrm{~A} /$ $\mathrm{dm}^{2}$ 位までで，これ以上 になると次第に亜鉛錯イオ ンの移動がにぶくなる。反 対側の陽イオン交換膜から は, 当然ナトリウムイオン の透析が盛えになっている から，透析残液からはシア ン化ナトリウムが減り，亜 鉛の割合がふ光る結果とな り，乙むいには水酸化亜鉛 の白い沈殿が生ずる。つま り亜鉛錯イオンのような大 きなイオンを透析するため には, 透析電流密度をあま り欲ばらないことでする。

な物， $1 \mathrm{~A} / \mathrm{dm}^{2}$ 位で透析していても，不 純物や沈殿などにより交換膜が目づをりを起 こし，実質の電流密度が大きくなっている場 合もあるので，透析槽に入る前に口過機など で固形物老除く必要が㸃ると思う。

\section{5. 濃いほうへ透析させると大きな イオンは通りにくくなる}

論より証拠で，1例としてシアン化亜鉛メ ッキ液を $1 / 20$ ～ $1 / 5$ と種々の割合で希勫した 液を調製して, 澧縮槽, 希釈槽化入れて, 膜 の両側の濃度差を変化させ, 透析電流 $1.5 \mathrm{~A} /$ $\mathrm{dm}^{2}, 3$ 時間後の移動量 $\left(\mathrm{mmmol} / \mathrm{dm}^{2}\right)$ を 求めた結果を表 2 に示した。

$1 / 5$ から $1 / 15$ 希积液へ透析するように，濃 い液から薄い液へ透析するときは，亜鉛錯イ オンのよらに大きなイオンもシアンイオンと 㐫まり異ならず，移動比も浴組成化近い值を 示している。
表 1 シアン化西鉛メッキ浴希釈液の透析実験 （透析電流之選択透過性）

\begin{tabular}{c|c|c|c}
\hline \multirow{2}{*}{ 透析 電流 } & \multicolumn{2}{|c|}{ 移動量 $\mathrm{mmmol} / \mathrm{dm}^{2}$ 膜・6 時間 } & \multirow{2}{*}{ 移動量モル比 } \\
\cline { 2 - 4 } & 全覀 鉛 量 & 全シアン量 & \\
\hline 透 析 前 & - & - & $1: 2.6$ (初期濃度比) \\
\hline $1 \mathrm{~A} / \mathrm{dm}^{2}$ & 28 & 74 & $1: 2.6$ \\
\hline $2 \mathrm{~A} / \mathrm{dm}^{2}$ & 29 & 132 & $1: 4.4$ \\
\hline
\end{tabular}

表 2 シアン化亜鉛メッキ浴希釈液の透析実験 （液濃度比と選択透過性）

\begin{tabular}{|c|c|c|c|c|}
\hline \multirow{2}{*}{$\begin{array}{l}\text { 希釈槽濃度 } \\
\left(\begin{array}{c}\text { メ哭浴 } \\
\text { 液希釈率 }\end{array}\right)\end{array}$} & \multirow{2}{*}{ 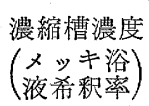 } & \multicolumn{2}{|c|}{$\begin{array}{l}\text { 移動量 } \mathrm{mmmol} / \mathrm{dm}^{2} \\
\text { 膜 } 3 \text { 時間 }\end{array}$} & \multirow{2}{*}{ 移動量モル比 } \\
\hline & & 全亜鉛量 & 全シアン量 & \\
\hline & & & & $1: 3.5$ (初期) \\
\hline $1 / 5$ & $1 / 15$ & 16 & 69 & $1: 4.3$ \\
\hline $1 / 10$ & $1 / 5$ & 9 & 44.5 & $1: 4.9$ \\
\hline $1 / 15$ & $1 / 5$ & 7 & 40 & $1: 5.7$ \\
\hline $1 / 20$ & $1 / 5$ & 5 & 41 & $1: 8.2$ \\
\hline
\end{tabular}

しかし逆に薄い液から濃い液へ透析させる と，覀鉛錯イオンの移動量はどんどん減少 し，1/20から $1 / 5$ と 4 倍の濃度差になると亜 鉛対シアンの比が $1 ： 8$ になでなってしま う。薄い液から濃い液へ動かすのは, るとる と自然の力に反する（エントロピーが減少す る）ことなので, 膜の吸着, 細孔通過, 脱離 などに大きなイオンほど妨害をうける。

このことは，亜鉛メッキ濃縮回収の実験で 最も困った現象であった。

衆知のように，亜鉛メッキシアン浴は常温 型が多く,メッキ液の蒸発がないので回収液 をメッキ槽に還元すると浴槽からあ心れてて まう。そこでイオン交換膜を使って，回収糟 からメッキ槽へイオンだけもどせば，液量は 変化なくて調子がよいだろうと考光てやって みたわけである。液もれは装置の構造でなく すことがでる。電気浸透で液がメッキ槽に移 動することも恐れていたが， $2 \mathrm{~A} / \mathrm{dm}^{2}$ 以下 
の電流密度では問題にするほどのことはなか った。透析電流を $2 \mathrm{~A} / \mathrm{dm}^{2}$ 以上流すと亜鉛 錯イオンの透析が減ってくるが, $1.5 \mathrm{~A} / \mathrm{dm}^{2}$ 以下にすれば大丈夫であった。このあたりま では成功だったのであるが，肝心の濃縮のと ころでつまずいてしまった。濃縮比をあげる ほど，車鉛の移動が減る。長時間続けると透 析電流を大きくしたときと同じく，白色の水 酸化覀鉛の沈殿が生じる。

規制のよりきびしいシアンが選択的に回収 されるので，公害対策上は望むしいことであ らうが，工程上は透析槽を多段式に使って少 しずつ濃縮するとか，水酸化物の口過除去装 置を加光るとか，複䧴に店らざるを得ない。

ところで, 前章のはじめに，なにが大きい イオンなのかについてちょっと述べたが，実 際上は単独イオン (水和水程度の弱い結合は 問題にならない) に対して, 複合されたイオ ンを大きいイオンとみればよいようである。

すなわち, ニッケルメッキ浴では, ニッケ ル, 塩素の各イオンが小さいイオンで, 硫酸 イオン, 添加剤が大きいイオンとなり，クロ ムメッキ浴で浊, クロム酸, 硫酸, ケイフッ 酸など，水素イオンを除いてみな大きなイオ ンとなる。銅メッキに物ける銅イオンは，硫 酸浴では小さいイオンであるが，シアン化銅 浴ではシアンイオンに囲をれて，大きな錯イ オンとなっている。亜鉛メッキは, シアン浴, ジンケート浴共に大さな亜鉛錯イオンが形成 されており, 酸性浴では単独の亜鉛イオンと なって小さなイオンに属するとみてよい。

シアンイオン (遊離) は, 炭素之窒素の結 合により形成されて祘り，単独イオンとはみ なせないが，このイオンはちょっと特殊で比 較的腰が軽く, 今回の透析実験でも小さなイ オンの部類に入る。もっとも, 水酸基よりは 大きいと思われるので，るう少し電流を増や したり，濃度差を大きくすると妨害を受ける ものと思われる。
添加剂怯，一般唖電荷の分子状溶解物 やイオンになっていても大きなイオンに属 して拈り，イオン交換膜を透析しにくいとみ られる。少しばかり透析できても，メッキ浴 組成には不足であり，分解不純物もあると思 われるので，むしろ透析前に活性炭など適当 な吸着剤で除去し，透析濃縮後新しい添加剤 を加觉な扮すほうがよい。

\section{6. おわりに}

先に“自然の力にさからっでといら言葉 を使ったが，これはイオン交換膜の特性を示 すのにぴったりした言葉である。

“マクスウェルの鬼”というものを昔の科 学者は想像した。これは速い分子と遅い分子 とが，まざっている室から一方の分子の灰を つまみ出す “マクスウェルの鬼”があれば， 一方の室は温度が下がり，他方はどんどん温 度が上昇することになる。

この活か，溶液から溶質のみを取り出すと か，水と炭酸ガスからデンプンを作るとか， いずれも自然の力(エントロピー増大の法則) にさからら反応は浮らって和いてできるもの ではなく，外から適当な力を加光て創りあげ

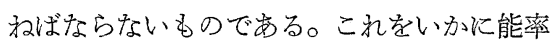
的行なうかが問題で, “マクスウェルの鬼” を求めて研究が行なわれているわけである。

イオン交換膜は, イオン交換樹脂, 触媒, 分子ふるいなどと共に，だいぶ“鬼”に近づ いた道具で岕る。

今回は色々と欠点ばかり述べてしまった が, これらの点は日進月歩に改良され, さら に種々の特性をもった交換膜の出現, 製造コ ストの引下げも期待される。今後, 表面処理 工程へのイオン交換膜の利用はさらに増光る ものと思われるので，なんらかの参考になれ ばと筆をとった次第である。

しい怙はじめ 名占屋市工業研究所 化学部長 理博 愛 知罧名古屋市熱田区六番町 3-24 